\title{
A STUDY ON CONSUMER PERCEPTION OF LUXERY DESTINATION IN TURKEY
}

DOI: 10.17261/Pressacademia.2015414470

\author{
Bilge Karamehmet ${ }^{1}$, Gokhan Aydin² \\ ${ }^{1}$ Istanbul Arel Universitesi. bilgekaramehmet@arel.edu.tr \\ ${ }^{2}$ Istanbul Arel Universitesi. gokhanaydin@arel.edu.tr
}

\section{Keywords \\ Conspicuous consumption, destination marketing, luxury tourism, conspicuous services marketing, luxury tourism marketing.}

JEL Classification M31, M30, Z33

\begin{abstract}
Luxury consumption has an increasing trend despite the recent global economic crisis. Luxury tourism and luxury hospitality are among the leading categories that drive luxury consumption. The definition of luxury as well the luxury tourism destinations is not a constant and may vary from an individual to another. The destination to be travelled is one of the important criteria determining luxury perceptions. In this study, consumers' luxury destination perceptions are sought to be determined in order to set a foundation to further develop upon in luxury destination studies that are in scarce supply in Turkey. This study area offers Turkey, which targets to achieve higher levels of tourism revenues in the next decade an important opportunity to realize this goal. The conspicuous luxury destinations and non-conspicuous destinations are determined by a two-stage survey study. The three conspicuous destinations appeared as Bodrum, Antalya and Çeşme as the outcome of the analysis carried out.
\end{abstract}

\section{TÜRKIYE'DE TÜKETICILERIN LÜKS DESTINASYON ALGISI ÜZERINE BiR ÇALIŞMA}

Anahtar Kelimeler Lüks tüketim, destinasyon pazarlaması, lüks turizm, lüks hizmet pazarlaması, lüks turizm pazarlaması

JEL Sınıflandırması M31, M30, Z33

\section{ÖZET}

Lüks tüketim günümüzde dünya genelinde yaşanan ekonomik krizlere rağmen yükselişte olan bir eğilimdir. Lüks ürünler içerisinde yer alan lüks konaklama hizmetleri ve lüks destinasyon turizmi lüks tüketimi ileriye taşıyan hizmetler arasında öne çıkmaktadır. Lüks kavramı ve dolayısıyla lüks destinasyon kavramı ise kişiden kişiye değişebilmekte, bölge tanımına bağlı olarak farklılaşabilmektedir. Bu çalışma içerisinde turizm alanında Dünya'nın önde gelen ülkeleri arasında yerini sağlamlaştırmaya çalışan Türkiye'de lüks destinasyon olarak algılanan yerler ortaya konulmaya çalışıış̧ıิır. Araştırmanın lüks destinasyon algıları ve tercihi ile ilgili tüketici davranışları araştırmaları için bir zemin hazırlaması hedefi güdülmektedir. Çalışma kapsamında Türkiye'de gösteriş̧̧i lüks destinasyon olarak algılanan bölgeler iki aşamalı bir çalışma vasıtasıyla tespit edilmiştir. Elde edilen verilerin analizi sonrasında bu üç gösteriş̧̧i bölge Bodrum, Antalya ve Çeşme olarak ortaya çıkmıştır. 


\section{GiRiş}

Latince "luxus" kökeninden gelen lüks kavramına literatürde farklı anlamlar yüklenmiştir. Bunlar arasında aşırıya kaçma, taşkınlık, savurganlık (Berthon, Pitt vd., 2009:46), ayrıca farklılaşma, ayrılma ve sapma anlamları da yer almaktadır. Bu bağlamda lüks marka satın alan tüketiciler, özenle oluşturulan ve nadir bulunan ürünler satın almanın verdiği duygusal değerden dolayı kendilerini toplumdaki diğer bireylerinden farklı bir yere oturtmakta, onlarla aralarına mesafe koymaktadırlar (Catry, 2003: 11). Heilman vd. (2006)'a göre lüks; bireylere mutluluk, tatmin, rahatlık veya kolaylık hissi veren veya bahsi geçen bu kavramlara düşkünlüğün olması ve zaruri olmayan bir olgu olarak tanımlanmaktadır. Lüks ürünlerin işletmeler ve pazarlamacılar için önemi ve gözde bir alan olması dünya çapında istikrarlı büyüme kaydederek önemli bir ekonomi haline gelmesine bağlanabilir. 2014 yılı içerisinde global lüks tüketim pazarı 2013 yılına kıyasla \%7'lik büyüme kaydetmiştir. Bahsi geçen bu büyüme içerisinde önemli bir yere sahip olan \%10'luk büyüme ile lüks araç ve \%9'luk büyüme ile lüks konaklama hizmetleri öne çıkmaktadır (Bain\& Company, 2014). Dünya çapında lüks ürün pazarı yeni yüzyılın başından beri hızla büyümeye devam etmektedir. Dünya çapında toplam pazar büyüklüğünün 2014 yılı sonuna kadar yıllık \%7 büyüme ile 850 milyar dolar olacağı tahmin edilmektedir (Bain \& Company, 2014). Avrupa pazarının tamamı özellikle Çin ve Amerika'nın artan turistik harcamalarından beslenen zayıf Euro'yu kullanarak 2015'e iyi bir başlangıç yapmıştır. Güney Avrupa iyileşme yolunda ilerlerken Batı Avrupa ses getirmiştir. Ancak Rusya'daki (ve dünyadaki Rusya harcamalarındaki) düşüş ani bir geri dönüş sinyali vermemekte; bu yıl pazarın yüzde 3-5 civarında büyümesi beklenmektedir (Bain \& Company, 2015).

Lüks tüketim alanında yapılan çalışmalar incelendiğinde gösterişçi tüketim ve statü tüketimi pazarlama alanında yapılmış olan çalışmaların çoğunda aynı olguyu açıklayan iki kavram olarak ortaya çıkmaktadır. Kilsheimer (1993:34) statü tüketimini "kişinin kendi çevresindekilere statüsünü veya prestijini göstermek amacıyla yaptığı gösteriş amaçlı tüketim olarak tanımlar. Yapılan çalışmalarda gösterişçi tüketim ve statü tüketimi kavramları birbirlerinin yerine kullanılan terimler olsa da araştırmacılar bu iki terimin birbiriyle ilişkili olduğunu fakat farklı kavramlar olduklarını savunmuşlardır (Eastman, Goldsmith ve Flynn, 1999:42; Roberts, Gwin ve Martinez, 2004: 64-65).

O'Cass ve McEven (2005:27)'e göre özellikle bazı ürün ve markalara sahip olmanın veya o ürün ya da markayı kullanmanın kullanıcıda yarattığı ruh hali, bir statü sembolü olarak algılanabilmektedir. Çünkü özellikle o ürünü ve/ya markayı kişinin satın alabilmesi, tüketicinin başarısı veya gücünün en belirgin göstergelerinden birisi olarak kabul edilmektedir. Tüketicilerin bu kapsamda yaptıkları alışverişlerin tamamının gösteriş amaçlı yapılmış olduğu kesin değildir. Bu açıklamalardan yola çıkarak O'Cass ve McEven (2005:27) gösteriş̧̧i tüketimi; tüketilen mal veya hizmetleri satın alması ve bu mal veya hizmetleri kişinin toplumdaki prestijini artırmak, toplumdaki diğer insanları etkilemek ve egosunu tatmin etmek için kullanması olarak tanımlamıştır.

Çevrelerindeki insanlara özenen kişilerin, onlar gibi olma/ görünme isteği ve çabası bulunmaktadır. Gösterişçi tüketimin asıl amacı satın alınan mal veya hizmetlerin mal ya da hizmetleri satın alan kişiye faydalı olmasından ziyade diğer kişiler tarafından açık bir biçimde zenginlik göstergesi olarak algılanmasıdır (Mason, 2001, Wong, 1997: 199). Bu durum aslında bireylerin çevrelerindeki kişilere satın alma güçlerinin ve zenginliklerini 
gösterme çabası olarak da değerlendirilebilir. Bahsi geçen bu çabalar sayesinde bireyler çevrelerindeki diğer kişilere zenginlik, farklılık ve statü sahibi bir gruba ait olduklarını gösterme imkanı bulmaktadırlar (Amaldoss ve Jain, 2005: 1450). Bu nedenle gösterişçi tüketimde özellikle lüks ve kolay erişilemeyen mal ya da hizmetler tercih edilmektedir. Bu kişiler özellikle toplum içinde tüketecekleri ürünlerin lüks ve pahalı olmasına dikkat etmektedirler (Eastman, Goldsmith ve Flynn, 1999: 43). Söz konusu bireylerin satın aldıkları üründen elde edecekleri tatmin düzeyini ekonomik veya fonksiyonel faydaların yerine çevrelerindeki diğer insanların ürüne vereceği tepki belirlemektedir. Bu bireylerin satın aldıkları ürün veya marka ile ilgili kendi çevrelerinden beğeni veya imrenme gibi tepkilerin verilmesi bireyin satın almış olduğu üründen tatmin olmasını sağlamaktadır (Chen, 2002: 43; Chen, Zhou ve Konektör, 2005: 199; Mason, 2001: 26)

Gösterişçi ve lüks tüketim davranış şekilleri kültürden kültüre değişkenlik göstermektedir. Bulunulan toplumun gösterişçi veya statü tüketim eğilimi kişinin bu davranışı belirgin şekilde yapması veya yapmaması şeklinde gerçekleşmektedir. Kolektif kültürlerde sosyal statü sembolleri veya toplumsal tabakalaşma diğer kültürlere oranla daha fazla görülmesiyle, bu toplumun içinde yaşayan kişilerin sosyal statülerini belirgin şekilde ortaya koymalarına diğer kültürlere oranla daha fazla olanak sağlayacaktır. Oysaki bireysel toplumlarda bireyler çevrelerindeki kişilerin kendileri ile ilgili ne düşündükleriyle değil kendi istek ve mutlulukları ile ilgilenmektedirler (Chen, 2002: 33).

Gösterişçi tüketim yüzyıllar boyunca batı dünyasında varlığını sürdürmüştür. Modern dünyadaki gösterişçi tüketim tanımı Veblen (1899)'in Aylak Sınıfı Teorisi ile endüstri devrimi sırasında belirginleşmiştir. Veblen bu teorisi ile ayrımcı sosyal sınıflandırmanın bir parçası olan gösterişçi tüketim sürecini ortaya koymuştur. Campbell (1994)'in notlarında belirttiği gibi Veblen- Simmel Modeli maddeler ve moda bireyleri gruplar halinde birleştirmeye ve onları hiyerarşik gruplara bölmeye çalıştığını varsaymaktadır. Ürünleri sergilemede bireylerin bir statü sisteminde konumlarını doğrulamada rol oynamaktadır. Bu yüzden farklı tabakalar arasındaki ayrım zenginlikteki farklardır. Veblen'e göre statünün göstergesi kişilerin birikimlerinin, kazançlarının büyüklüğünden ziyade zenginliğin göstergesi, kanıtları olarak şekil bulmaktadır.

\section{LITERATÜR TARAMASI}

\subsection{Lüks Tüketim Güdüleri}

Lüks tüketim satın alma motivasyonlarını ölçen araştırmalar doğrultusunda, satın alma motivasyonları içsel ya da dışsal olarak iki ana başlık altında kapsamlı bir şekilde sınıflandırmaktadır. iç odaklı (içsel) satın alma, kişinin içsel tatmin hedeflerini yansıtmaktadır (Tsai, 2005). Dışsal motivasyonlar olarak ise makale içerinde daha önce değinilen gösterişçi tüketim, statü ve başarıyı gösterme, bir referans gruba ait olma gibi güdülerden oluşur. Dışsal güdüler kendi zenginlik ve statülerini belirtmek için bireylerin lüks malları satın almasını belirten gösterişçi tüketim teorisi kapsamına girmektedir (Veblen, 1899). Bireylerin kendini daha iyi görme/gösterme güdüleriyle alt tabakada yer alanların daha üst sosyal tabakaya ait görünmek istemesi, üst tabakalarda yer alanların ise alt tabakadan farklılaşma istekleri sonucunda gösterişçi tüketim eğilimleri ortaya çıkmaktadır. 
Popüler ekonomiye nispeten yeni ve özellikle ilgi çekici olarak tabir edilebilecek bir fikir vardır. Bu fikir, herhangi bir mal ya da hizmetin kullanımından elde edilen yararın iki ölçülebilir türü olduğunu savunmaktadır. Bunlar kullanıcıya doğrudan faydacıl kavramı ile mal ya da hizmet tüketiyor görünmesinin sonucu olarak kullanıcıya fayda sağlayan gösterişçi kavramıdır (Bassman, Molina ve Slottje, 1988).

Lüks ürünler satın almada içsel isteklere önem veren tüketiciler gösterişçi tüketim için değil kalite ve öz yönelimli zevk için lüks ürünler satın almaktadırlar (Amatulli ve Guido, 2012). İçsel güdü olarak sınıflandırabileceğimiz kendini gerçekleştirme ve hedonik (hazsal) tatminin tüketicileri lüks tüketime yönelttiği farklı çalışmalarda gözlenmiştir (Truong ve McColl, 2011). Hedonik tüketim kişinin ürünle deneyimlediği duygusal görünüş ve çoklu duyumsal fanteziyle ilgili olan tüketici davranışlarının yönlerini belirlemektedir. Hedonik değer kendi fonksiyonel fayda ile elde edilen değerden ziyade eğlence ve haz sebebiyle ortaya çıkar, daha öznel ve bireyseldir (Hirschman ve Holbrook 1982, 92).

Marcoux, Filiatrault ve Cheron (1997) yaptıkları çalışmada öğrencilerin gösteriş̧̧i tüketim davranışlarını Amerika ve Polonya menşeli marka tercihleri doğrultusunda belirlemeye çalışmışlardır. Araştırma sonuçlarına göre araştırmaya katılan bireyler arasında gösterişçi tüketim oldukça yaygındır ve Amerika menşeli markalar katılımcılar tarafından daha çok tercih edilmektedir. Bu çalışma sonucunda ayrıca beş boyutlu gösterişçi tüketim ölçeği geliştirilmiştir. Bu boyutlar; materyalist hedonizm, bir gruba ait olma veya diğer insanlardan farklı olmayı gösterme, sosyal statü göstergesi, kişilerarası arabuluculuk ve gösteriş olarak sıralanmaktadır.

Wong (1997) yaptığı çalışmada gösterişçi tüketim, materyalizm ve benlik arasındaki ilişkiyi incelemiştir. Araştırma sonuçlarına göre materyalist olan ve sosyal benliğe önem veren kişilerde gösteriş̧̧i tüketim eğiliminin daha fazla olduğu ortaya çıkmıştır.

Eastman vd., (1999) statü tüketimi ve materyalizm arasındaki ilişkiyi Amerikalı, Çinli ve Meksikalı öğrenciler üzerinde kültürler arası bir çalışma yaparak incelemişlerdir. Yapılan çalışmada katılımcıların materyalizm ve statü tüketimine farklı bakış açılarına sahip olduğunu ancak her üç kültürde de statü tüketimi ve materyalizm arasında ilişki olduğu ortaya çıkmıştır. Eastman vd. (1999) yaptıkları çalışmada statü tüketimini açıklayarak, statü tüketimi ölçeğini geliştirmişlerdir.

Chen (2002) Çinlilerin gösteriş̧̧i tüketim davranışları üzerinde kişilerin materyalist olması ve farklı kültürde olmalarının etkilerini incelemiştir. Kanada'da yaşayan Çinlilerin bulundukları kültürden etkilenme düzeyleri ve bu durumun gösteriş̧̧i tüketimine etkisi incelenmiştir. Araştırmaya göre farklı kültürlerde yaşayan insanlar kendi kültürleri ve içinde bulundukları kültürün etkilerini taşımaktadır. Kanada'da yaşayan Çinlilerde gösterişçi tüketim eğiliminin fazla olduğu ortaya çıkmıştır.

Goldsmith vd. (2006) gösterişçi tüketim konusunu farklı bir bakış açısıyla ele almış, Feick ve Prince (1987) 'in tanımladığı pazar kurtlarının demografik özelliklerini tespit etmeye ve pazar kurdu olma, statü tüketimi ve kişilerin yenilikçilikleri arasındaki ilişkiyi araştırmıştır. Pazar kurtlarını tanımlamada demografik özelliklerin belirleyici olmadığını, yenilikçi olma ve statü tüketiminin daha fazla açıklayıcı olduğunu tespit etmiştir.

Heaney, Goldsmith ve Jusoh (2005) Malezya'da öğrenciler üzerinde yaptıkları çalışmada materyalizm, farklılık ve statü tüketimi arasındaki ilişkiyi incelemişlerdir. Çalışmada 
materyalizm ve statü tüketiminin birbirinden farklı ancak birbirleriyle ilişkili kavramlar olduğu belirtilmiştir. Roberts (2000)'ın Teksas'ta öğrenciler üzerinde yaptığı araştırmada takıntılı alışveriş, materyalizm ve statü alışverişi arasındaki ilişki incelenmiştir. Araştırma sonucunda materyalist ve statü alışverişi eğilimi yüksek olan kişilerde takıntılı alışveriş daha fazla görüldüğü ortaya çıkmıştır.

Roberts, Gwin ve Martinez (2004)'in birlikte yaptıkları bir araştırmada bireyin ailesinin mal varlığı, yapısı ve tüketim eğiliminin takıntılı alışveriş ve materyalizm üzerindeki etkisinin yanında ara değişken olarak statü tüketimi arasındaki ilişkiyi de araştırmaya dahil ederek incelemişlerdir. Araştırma bireyin ailesinin materyalist olup olmaması, ailenin bir arada veya bölünmüş olması (ölüm, ayrılma) ve ailenin statü tüketimi eğiliminin olması ile takıntılı alışveriş arasında ilişki olduğu ortaya çıkmıştır. Materyalist ve bölünmüş olan ailelerde statü tüketimi ve takıntılı alışveriş eğiliminin daha yüksek olduğu ortaya çıkmıştır.

O'Cass ve McEwen (2005)'in yaptıkları çalışmada kendini gösterme, cinsiyet, kişiler arası iletişim ve bu değişkenlerin statü ve gösteriş̧̧i tüketim üzerindeki etkisini ve statü ve gösterişçi tüketim kavramlarının farklılıklarını araştırmışlardır. Araştırmanın sonucunda statü ve gösterişçi tüketim ilişkili ancak farklı olgular olduğu belirtilmiştir. Ayrıca cinsiyetin gösterişçi ve statü tüketimde belirleyici bir rolü bulunduğunu, kadınlarda statü ve gösterişçi tüketim eğiliminin daha fazla olduğunu savunmuşlardır. Benzer şekilde referans grubundan etkilenme her iki tüketim şeklinde de etkileyici role sahip olduğu ancak kendini gösterimin statü tüketimi ile ilişkili, gösterişçi tüketim ile ilişkili olmadığı ortaya koyulmuştur. Araştırma sonucunda kendini gösterimi yüksek olan kişilerde statü tüketimi yapma eğilimi daha fazla olduğu ortaya çıkmıştır. Gösterişçi tüketim ile çoğunlukla materyalizm, benlik algısı, demografik özellikler arasındaki ilişkiler ele alınmış ve incelenmiştir. Araştırmacılar özellikle sosyal benliğe önem verenlerde bu gösterişçi tüketim eğiliminin olduğunu belirlemişlerdir. Bu bakış açısıla benlik, gösterişçi tüketimi açıklamada önemli bir parçayı oluşturmaktadır.

Eastman vd. (1999: 43) 'ne göre statü elde etme arzusu statü ürünlerine duyulan isteği ortaya çıkarmaktadır. Statü tüketiminin temelinde bireyin kendisine ya da kendi çevresindeki diğer bireylere statü temsil eden bir ürünü satın alma arzusu yatmaktadır. Gösteriş tüketiminin temelinde ise; bireyin kendi egosunu tatmin etmek amacıyla pahalı bir ürünü satın alma çabası yatmaktadır. Bunun yanında bir bireyin statü sembolü olarak kabul gören herhangi bir ürünü satın alması, bireyin kendine olan saygısı ve çevresindeki bireyler tarafından onay görme konularında kendisine yardımcı olduğu ortaya çıkmıştır. Bireyin statü arayışı arttıkça, statü gösterimi güçlü ürünleri satın alma eğilimi de artacaktır (Eastman, vd., 1999: 43).

O'Cass ve McEwen'a göre (2005: 27); statü ve gösteriş tüketimi kavramları arasındaki bir diğer önemli fark; kişinin çevresinde yer alan diğer bireylerin satın alınan ürünü görmeleri/görmemeleri gerekliliği bağlamında ele almışlardır. Yaptıkları araştırmaya göre, statüyü temsil eden herhangi markanın iç çamaşırını giyen bir birey statü tüketimi açısından değerlendirildiğinde, birey bu marka bir iç çamaşırına sahip olarak markanın temsil ettiği statüyü yalnızca çevresine değil kendisine de kanıtlamaktadır. Bireyin sahip olduğu ürün; statüyü temsil eden markalı bir iç çamaşırı olduğu için birey bunu çevresinde yer alan diğer bireylere gösterememektedir. Bu bağlamda statü tüketimi ve gösteriş 
tüketimi arasındaki fark, bireyin satın aldığı ürünü çevresindekilere gösterme zorunluluğu olarak da ortaya konabilmektedir.

Tüm bu açıklamalar ışığında, konu turizm açısından ele alındığında ise lüks tüketimin yukarıda da belirtilen yurt içi ve yurt dışında yapılmış olan konuyla ilgili tüm araştırmalarda göze çarpan bir konu olduğu görülmüştür. Statü elde etme arzusunun turizm pazarlaması açısından ve turizm destinasyon pazarlaması penceresinden incelenmesinin hem literatüre hem de uygulamaya katkısı olacağı düşünülmüştür.

\subsection{Destinasyon Pazarlaması}

Çoğunlukla statü elde etmek isteyen tüketici ve/ya kalite ve öz yönelimli zevk için lüks ürünler satın alan tüketiciler ile bunları arz edenlerin buluşma noktası olan destinasyonların pazarlanması konusu, ilgili bölümde de bahsedildiği gibi büyük önem taşımaktadır. Turizm destinasyonlarının pazarlama analizlerinden önce turizm destinasyonu kavramına açıklık getirmek gerekmektedir. Konuyla ilgili genel tanımlar aşağıdaki gibidir.

Hosany vd. (2006:638) turizm destinasyonunu belli bir imaja sahip; markalaşmış, turistik çekiciliklere ve çekim merkezlerine, çeşitli etkinliklere ev sahipliği yapan/ yapabilecek potansiyeli olan, bölge içi ve bölgeler arası yeterli bir ulaşım ağına, gelişim potansiyeline ve turistik tesislerin yatırımı / gelişimi için yeterli potansiyele sahip ülkeden küçük kentten büyük bölge olarak tanımlamaktadırlar.

Turizm destinasyonundan söz edebilmek için aynı kültür, iklim ve doğa koşullarına sahip, doğal ve kültürel zenginlikleri olan, müşterilere sunulabilecek o bölgeye özgü aktiviteler geliştirmiş, konaklama, beslenme, ulaşım ve iletişim olanaklarına sahip, kamusal hizmetlerin sunulduğu turist çekim merkezlerinden oluşan, belli bir marka ve imajı bulunan coğrafik alan olmalıdır (Ersun ve Kahraman, 2011:9).

Destinasyon yönetim örgütleri, iş amaçlı ya da tatil amacıyla seyahat etmeyi düşünen turistleri çekmek için koordinasyon çabası içinde olan örgütlerdir. Destinasyon yönetim örgütlerinin emel amacı, herhangi bir bölgeyi bir turizm destinasyon markası olarak konumlandırma ve tanıtım yoluyla arz edenler için talep edenleri bir araya getirmektir. (Pollock, 1996:27).

Turizm destinasyonlarının etkin yönetilmesi, destinasyonunun özelliklerinin iyi irdelenmesi, kaynaklarının koordine edilmesi ve arzu edilen düzeyde talep yaratacak şekilde pazarlanabilmesi gibi unsurlara bağlıdır. Destinasyonun sahip olduğu ürünler ve hedef kitle, destinasyon yönetimini de etkileyebilmektedir. Bu bakımdan, her bir destinasyon için ortaya konulan yönetim programının da farklılık göstermesi beklenir. (Atay ve Akyurt, 2007:543)

\subsection{Türkiye'de Gerçekleştirilmiş ilgili Çalışmalar}

Lüks markaların Türkiye'de geldiği konuma bakıldığında, geçtiğimiz yıllara göre Türkiye'deki lüks markaların geliştiği ve sayılarının da artış gösterdiği söylenebilir. Ekonomik ve kültürel değişimlerin verdiği sonuçlar ile Türk halkı lüks tüketime eğilimli hale getirilmiştir. (Ceritoğlu,vd. 2008:537). 
Bain \& Company'nin (2015) küresel lüks mallar piyasası araştırmasında; 2015 yılında Avrupa pazarının yüzde 2-4 reel büyüme ile sürekli ivme kazanacağı beklenmektedir.

Ülkemizde yapılan lüks destinasyon turizmi ile ilgili olabilecek araştırmalar incelendiğinde destinasyon imaj çalışmalarının ağırlıkta olduğu görülmektedir. Ülkemizde turizm içerikli pazarlama faaliyetleri makro düzeyde ele alınmakta ve ağılıklı olarak "ülke tanıtımı" şeklinde sürdürülmektedir (Ersun, N., ve Arslan K., 2011:229).

Türkiye'de yapılan destinasyon markalaması araştırmalarından birisinde incelenen Alanya beldesinin araştırmanın sonucunda bir marka olarak araştırmaya konu olan diğer destinasyonlardan ayırt edici bir özelliğinin olduğu belirlenmiştir. Ancak değer açısından düşük olduğu da araştırma bulgularında saptanmıştır (Kavacık, vd., 2012). Benzer şekilde Üner, vd. (2006:189)'nin çalışmasında İstanbul'un yükselen destinasyon olarak imajı incelenmiş ve Antalya, İstanbul ve Nevşehir gibi önemli turistik destinasyonların hedef ülke pazarlarındaki imajlarına yönelik çalışmalarının yapılmasının doğru olacağı vurgulanmıştır.

Turistik çekicilik kavramlarının tanımlandığı turizmde destinasyon çekiciliğini araştıran bir diğer çalışma da turizm planlamasının destinasyon çekiciliğine ne denli etki ettiğini açıklamaktadır (Kutvan ve Kutvan, 2013:159)

Ayyıldız ve Turna (2012)'nın turizm destinasyon imajı üzerine yaptıkları çalışmada duygusal ülke imajının bilişsel ülke imajına göre daha etkili olduğu; turistlerin, kültürel çekiciliklere önem verdikleri bu nedenle turist çekmek isteyen ülkelerin, dil, mutfak, yaşam tarzı gibi kültürel unsurlarını ön plana çıkarmaları gerektiği ortaya çıkmıştır.

Türkiye'de lüks tüketim konusunda turizm alanında yapılmış çalışmaların kısıtlı sayıda olması sebebiyle ülkemizde önemi ve ekonomiye katma değeri gittikçe artan bu alanda yeni araştırmalar yapma gerekliliği ortaya çıkmıştır.

\section{DATA VE METODOLOJi}

Gösterişçi lüks tüketim pazarı içerisinde önemli bir alan turizm kategorisi içerisinde yer almaktadır. Lüks seyahat ve tatil destinasyonları lüks tüketimin hızlı büyüyen alanlarından önemli bir tanesini oluşturmaktadır. Tatil destinasyonu seçimi tüketicinin takdirinde olduğundan gösteriş̧̧i tüketim çalışmaları için tatil destinasyonu seçimi iyi bir örnek olacaktır.

Gösterişçi tüketim konsepti tüketicilerin Maldivler ve Paris gibi lüks ya da prestijli destinasyonlar seçerek başkalarını etkilemek için çıktıkları ekonomik başarılarını ve statülerini göstermek isteklerini açıklayabilir. Ekonomik gücünü göstererek lüks tesisleri ziyaret edebiliyor olmak, başkalarına sosyal benlik imajlarını prestijli göstermekte ve kişinin toplumdaki pozisyonunu yükseltmektedir. Ancak bu olgu, destinasyon seçimi yapan bazı turistler için diğerlerinden daha anlamlı olabilir. Bunlar sosyal konuma büyük değer verme ve mal ya da hizmetleri tüketim ve satın alma yoluyla sosyal statülerini göstermek için daha prestijli, göze çarpan ve dikkat çekici yerleri ziyaret eden kişilerdir.

Oysaki bazı bireyler başkalarını etkilemek için gösterişçi destinasyonları ziyaret etmek konusunda ilgisizlerdir. Bu alanda yapılmış olan diğer tüketici araştırmaları gösterişçi ve gösterişçi olmayan tüketimleri tanımlayarak farklılaştırmışlardır (Kaiser, 1990; Goldsmith, Flynn, ve Eastman, 1996; Wong ve Zhou, 2005). Araştırma bulgularına göre bir turizm 
destinasyonunun diğer turizm destinasyonundan daha gösterişçi olarak algılamak ve varsaymak mümkündür.

Böylece turizmde gösterişçi ve gösterişçi olmayan destinasyonları tanımlayarak gösterişçi tüketim motivasyon çalışması yürütmek mümkün hale gelmiştir. İkincisi ise gösterişçi destinasyonların karakteristik özelliklerinin araştırılması gerekliliğidir. Turistlerin bir destinasyonu gösterişçi olarak adlandırmalarına sebep olan nedir? Bir diğer cevaplanması gereken soru ise gösterişçi destinasyonların boyutları nelerdir? Bu çalışma içerisinde yöntem bölümünde detaylandırıldığı şekilde 2 aşamalı bir anket çalışması ile Türkiye'deki gösterişçi ve gösterişçi olmayan destinasyonların belirlenmesine çalışılmıştır.

\subsection{Yöntem}

1. Aşama: Bu aşamada katılımcıların akıllarına ilk gelen 3 farklı gösterişli ya da şatafatı olduğunu düşündükleri tatil bölgesini yazmaları istenmiştir. Ayrıca buna benzer şekilde katılımcılar akıllarına ilk gelen 3 gösterişsiz ya da şatafatsız tatil bölgesi tercihlerini de belirtmişlerdir.

2. Aşama: illk aşama tamamlandıktan sonra çıkan sonuçlar üzerinden ikinci bir anket çalışması yapılmıştır. Bu aşamada katılımcılardan bir önceki adımda ortaya çıkan bölgeleri değerlendirmeleri istenmiştir. Bu aşamada kendilerine sunulan tatil beldelerini ne kadar gösterişçi oldukları dokuz ölçekli bir semantik ölçekte değerlendirmeleri istenmiştir.

\subsection{Model}

Şekil-1 içerisinde görülmekte olan model gösterişçi tüketim alanında mevcut olan ve genel kabul gören literatürden faydalanılarak geliştirilmiştir. Daha önce değinildiği üzere tüketicilerin gösterişçi tüketimi tercih etmelerinin altında yatan farklı sebepler, güdüler bulunmaktadır. Literatürde bu farklı güdülere dayanılarak geliştirilmiş olan farklı gösterişçi tüketim eğilimi ölçekleri bulunmaktadır. Bu çalışma içerisinde bu ölçeklerden destinasyon turizmi alanına uygulaması daha önce Philips vd. (2013) tarafından ABD'de gerçekleştirilmiş ve ölçeğin güvenilirlik ve geçerliliği test edilmiş olan Marcoux vd. (1997) çalışmasına dayandırılmıştır. 


\section{Şekil 1: Model}

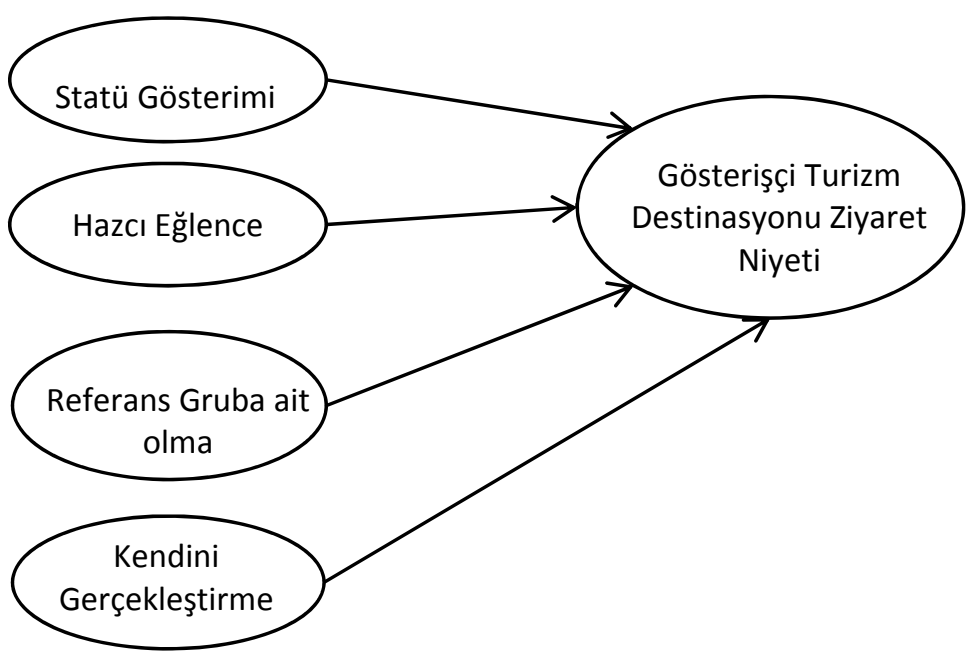

Lüks tüketim literatürü içerisinde sıklıkla rastlanan statü gösterimi, kendini referans gruba ait hissetme ve gösterme, öz tatmin ve kendini gerçekleştirme ve yapılan alışveriş ve tüketimden haz duyma eğlenme başlıklarının tamamına model içerisinde yer verilmiştir.

\section{AMPIRIK BULGULAR}

Bu çalışma içerisinde ilk olarak Türkiye'deki gösterişçi turizm ve gösterişçi olmayan turizm destinasyonlarının belirlenebilmesi için Üniversite öğrencileri, akademisyenler ve üniversite idari çalışanları içerisinden 52 kişiye kısa bir anket çalışması uygulanmıştır. Bu anket çalışması kapsamında Türkiye'de gösterişli/şatafatlı ya da göze çarpan bir yerde tatil yapmak istediklerinden nereleri tercih edecekleri sorgulanmıştır. Benzer şekilde gösterişsiz/şatafatsız ya da göze çarpmayan bir yerde tatil yapmak istenildiğinde tercih edilen yerler de anket içerisinde katılımcılara sorulmuştur. Bu anketin sonuçları doğrultusunda gösterişli ve gösterişçi olmayan olarak en çok değinilen üçer destinasyon belirlenmiştir. Bu destinasyonlar gösterişçi turizm için Bodrum, Antalya ve Çeşme; gösterişçi olmayan turizm için ise Karadeniz, Güneydoğu ve Ayvalık olarak ortaya çıkmıştır. Bu anket kapsamında elde edilen bilgilerin bir özeti Tablo-1 içerisinde görülmektedir.

Tablo 1: İlk Aşama Sonuçları*

\begin{tabular}{|l|l|l|l|}
\hline Gösterişli Bölge / Şehir & Kişi Sayısı & Mütevazi Bölge/ Şehir & Kişi Sayısı \\
\hline Bodrum & 29 & Karadeniz & 14 \\
\hline Antalya & 26 & Güneydoğu & 9 \\
\hline Çeşme & 18 & Ayvalık & 8 \\
\hline İstanbul & 8 & Kapadokya & 8 \\
\hline İzmir & 8 & Bozcaada & 5 \\
\hline
\end{tabular}

* illk 5 sonuç gösterilmektedir. 
Çalışmanın ikinci bölümünde ise, ilk çalışma sonrasında belirlenen bu üçer bölge için doğrulayıcı bir çalışma yapılarak her bir bölgenin ne derecede gösterişçi olarak algılandığı ilk çalışmadan farklı bir örnekleme anket yöntemiyle sorularak ortaya konulmuştur. Çalışmanın ikinci safhası sonucunda elde edilen açıklayıcı bulgular Tablo-2 içerisinde sunulmaktadır.

Tablo 2: İkinci Aşama Sonuçları*

\begin{tabular}{|l|c|c|}
\hline $\mathbf{N}: \mathbf{1 0 1}$ & Ortalama & Std. Sapma \\
\hline Bodrum & 7,43 & 1,79 \\
\hline Antalya & 6,95 & 1,96 \\
\hline Çeşme & 7,30 & 1,96 \\
\hline Karadeniz & 5,17 & 2,71 \\
\hline Güneydoğu & 4,48 & 2,56 \\
\hline Ayvalık & 5,96 & 2,11 \\
\hline
\end{tabular}

* Katılımcılar belirtilen tüm destinasyonları 1'den 9'a kadar (1: Gösterişsiz, 9: Gösterişli/ şatafatlı) puan vererek değerlendirmiştir.

Anket sorusuna verilen cevapların ortalama değerleri ve standart sapmaları Tablo 2 içerisinde görülmektedir. Bu veriden hareketle Bodrum, Antalya ve Çeşme gösterişçi destinasyonlar olarak ikinci denek grubu tarafından onaylanmaktadır. Yine benzer şekilde Karadeniz, Güneydoğu ve Ayvalık bölgeleri de gösterişçi olmayan mütevazi tatil beldeleri olarak doğrulanmaktadır. Özet olarak gerçekleştirilen ikinci çalışmanın sonuçları birinci çalışmada elde edilen bulguları doğrular niteliktedir.

\section{SONUÇ}

Bu çalışma gösterişçi tüketimin destinasyon turizminde yerinin anlaşılabilmesi için bir ön çalışma niteliğinde olup bu çalışmayı takiben yapılacak olan gösterişçi lüks turizm tercihinde motivasyon çalışmalarına zemin hazırlamak amacını gütmektedir. Bu amaç doğrultusunda ve çalışma içerisinde "Model" başlığı altında kurgulanmış olan gösterişçi tüketim motivasyon modelinin test edilebilmesi için Türkiye'de gösterişçi turizm ve gösterişçi olmayan turizm destinasyonları olarak algılanan yerlerin belirlenmesi sağlanmıştır. Lüks destinasyon pazarlaması ile ilgili hazırlanan bu zemin ve belirlenen bu destinasyonların ilgili alanda çalışacak olan araştırmacılara kaynak olması beklenmektedir. Çalışmanın kuramsal olarak akademik literatüre katkı sağlaması ve ileride gerçekleştirilecek çalışmalar vasıtasıyla dolaylı olarak turizm ve pazarlama uygulamalarına katkı sağlaması beklenmektedir.

Araştırmanın kısıtları arasında sayabileceğimiz ilk başlık araştırmanın uygulama aşamasında sayı olarak kısıtlı ve dar demografik özelliklere sahip bir örneklem ile çalışımış olmasını verebiliriz. Ayrıca gerçekleştirilmiş olan çalışmanın bulgularının bu haliyle turizm işletmecileri için uygulamaya doğrudan değer yaratması beklenmemekte, sonuçların teorik çalışmalara zemin hazırlaması hedeflenmektedir. 


\section{KAYNAKÇA}

Amaldoss, W., and Jain, S. (2005), Conspicuous Consumption and Sophisticated Thinking, Management Science, 51(10), p.1449-1466.

Amatulli, C. and Guido, G. (2011), Determinants of purchasing intention for fashion luxury goods in the Italian market: A laddering approach. Journal of Fashion Marketing and Management, 15(1), p.123-136.

Atay, L. ve Akyurt, H. (2007), "Turizm Endüstrisinde Destinasyon Yönetimi”, Sürdürülebilir Rekabet Avantajı Elde Etmede Turizm Sektörü Sektörel Stratejiler ve Uygulamalar, URAK Uluslararası Rekabet Araştırmaları Kurumu Derneği, İstanbul, s.543

Ayyıldız, H., ve Turna, B. G. (2012), Turizm Destinasyon İmajının (TDI) Uluslararası Tüketici Davranışına Etkisi, XVII. Ulusal Pazarlama Kongresi Pazarlamada Kültür ve Eğitim Paradigması, Balıkesir, p.417-436.

Bain \& Company. (2014), Luxury Goods Worldwide Market Study Fall-Winter 2014. [URL: http://www.bain.com/publications/articles/luxury-goods-worldwide-market-study-december-2014.aspx] (Erişim 09 Nisan 2015).

Bain \& Company. (2015), Global luxury goods market expected to sustain steady momentum [URL: http://www.bain.com/about/press/press-releases/spring-2015-worldwide-luxury-goods-update-pressrelease.aspx] (Erişim 18 Ağustos 2015).

Basmann, Robert L., Molina, David J., and Slottje, Daniel J. (1988), A Note on Measuring Veblen's Theory of Conspicuous Consumption, Review of Economics and Statistics 70, p.531-535.

Berthon P.,Pitt L., Parent M., and Berthon J. (2009), Aesthetics and Ephemerality: Observing And Preserving The Luxury Brand, California Management Review, 52(1), p. 45-66.

Catry, B. (2003), The Great Pretenders: The Magic of Luxury Goods, Business Strategy Review, 14, p.10-17.

Ceritoğlu B.,Baumgarth C., and Schneider G. (2008), Lüks Markalar Gerçekten Güçlü Markalar mı? Türkiye'deki Temel, Premium ve Lüks Markaların Faydaları ve Marka Güçlerine İlişkin Ampirik Bir Çalışma, Marmara Üniversitesi i.i.B.F. Dergisi, 25(2), p.535-564.

Chen, J. (2002), Chinese Identification, Acculturation and Conspicuous Consumption in a Multicultural Society: A Theoretical Framework and Emprical Evidence, Michigan: The University of Guelph, UMI.

Chen, J., M. Aung, Zhou, L., and Konektör, V. (2005), Chinese Ethnic Identification and Conspicuous Consumption: Are There Moderators or Mediators Effect of Acculturation Dimensions?, Journal of International Consumer Marketing, 17(2/3), p.117-136.

Eastman, K.J., Goldsmith, R.E. and Flynn, L.R. (1999), Status Consumption in Consumer Behaviour: Scale Development and Validation, Journal of Marketing Theory and Practice. Summer, p.41-52.

Ersun, N. ve Kahraman, A. (2011) Turizmde Destinasyon Seçimini Etkileyen Temel Unsurlar ve Pazarlama Stratejileri, Marmara Üniversitesi i.i.B.F Dergisi, 31 (2), p.229-248.

Feick, Lawrance F., and Price, Linda L. (1987). The Market Maven: A Diffuser of Marketplace Information, Journal of Marketing, Vol.51, January, p.83-97.

Goldsmith, R.E., Clark, R.A. and Goldsmith, E.B. (2006), Extending the Psychological Profile of market Mavenism, Journal of Consumer Behaviour, 5, p.411-419.

Heaney, J.G., Goldsmith, R.E. and Jusoh, W.J.W. (2005), Status Consumption Among Malaysion Consumers: Exploring Its Relationships with Materialism and Attention-to-Social-Comparison-Information, Journal of International Consumer Marketing, 17(4), p.83-98.

Heilman, C.M.,Kaefer, F. and Ramenofsky, S. D. (2006), Luxury Good Expenditures of Husband and Wife Dyads Incorporating User Attitudes. Association for Consumer Research Conference. Utah: Provo.11th. December.

Hirschman, E.C. and M.B. Holbrook (1982), Hedonic Consumption: Emerging Concepts, Methods and Propositions, Journal of Marketing (46)3, p.92-101.

Hosany, S., Ekinci, Y. ve Uysal, M. (2006), Destination Image and Destination Personality: An Application of Branding Theories to Tourism Places, Journal of Business Research, (59), p.638.

Kaiser, S. B. (1990). The social psychology of apparel (2nd ed.). New York, NY: Macmillan. 
Kavacık, M., Zafer, S. ve Inal, M.E. (2012), Turizmde Destinasyon Markalaması: Alanya Örneği, Erciyes Üniversitesi IiBF Dergisi, Sayı: 39, p.169-192.

Kilsheimer, J.C. (1993), Status Consumption: The Development and Implications of A Scale Measuring the Motivation to Consume For Status, Michigan: The Florida State University, UMI.

Kutvan, A.B., ve Kutvan, S. A. (2013), Turizm Planlamasında Destinasyon Çekiciliklerinin Ölçümü: Bir Yöntem Yaklaşımı, International Journal of Economic and Administrative Studies, 6(11), p.159-184.

Marcoux, J.S., Filiatrault, P., and Cheron, E. (1997), The Attitudes Underlying Preferences of Young Urban Educated Polish Consumers Towards Products Made in Western Countries, Journal of International Consumer Marketing, 9(4), p.5-29.

Mason, R. (2001), Conspicuous Consumption: A Literature Review, European Journal of Marketing, 18(3), p.2639.

O'Cass, A., and McEwen, H. (2005), Exploring Consumer Status and Conspicuous Consumption, Journal of Consumer Behaviour, 4(1), p.25-39.

Pollock, A. (1996), The Role of Electronic Brochures in Selling Travel: Implications for Businesses and Destinations", Australian Journal of Hospitality Management, 3(1), p.27.

Roberts, A.J. (2000), Consuming in a Consumer Culture: College Students, Materialism, Status Consumption, and Compulsive Buying, Marketing Management Journal, (Fall/Winter), p.76-91.

Truong, Y., and McColl R. (2011), Intrinsic motivations, self-esteem, and luxury goods consumption. Journal of Retailing and Consumer Services. 18, p.555-561.

Üner, M.M., Güçer, E., ve Taş̧̧ı, A. (2006), Türkiye Turizminde Yükselen Destinasyon Olarak istanbul Şehrinin İmajı, Anatolia: Turizm Araştırmaları Dergisi, 17(2), Güz, p.189-201.

Wong, N.Y.C. (1997), Suppose You Own the World and No One Knows? Conspicuous Consumption Materialism and Self, Advances in Consumer Research, 24, p.197-203. 